\title{
Determinants Of Financial And Retirement Planning: A Female Perspective
}

Naveen Malhotra, Eckerd College, USA

Maureen Witt, RBC Capital Markets, USA

\begin{abstract}
The good news is that only $6 \%$ of senior citizens in the United States live in poverty, however, the bad news is that $75 \%$ of seniors in poverty are women. The challenge for women is to develop an investment plan that will enable them to reach financial freedom by the time they are ready to enjoy retirement. Early recognition of obstacles due to gender-differences is the first step towards financial nirvana. Women need to understand that the best way to achieve their goals is by taking an active role in the financial planning process at an early age and staying the course. The numerous financial education resources available can help women gain confidence to empower themselves to face the challenges of retirement planning with a renewed vigor.
\end{abstract}

Keywords: Retirement planning, Investment Planning, Women and Investing, Female Psychological factors in investing

\section{INTRODUCTION}

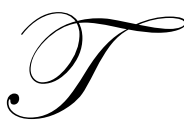

his paper addresses how and why women fall behind men in their financial and retirement planning and what they can do to overcome inertia. The process needs to be a part of a routine they follow, similar to an exercise regime. Just as a woman would periodically visit her doctor for a health checkup, she must also pay attention to her financial health as well. It is imperative to acknowledge that time is of the utmost importance. Whatever ages a woman might be or where she is in her career, it is never too late to begin an investment plan. Time can be a female's greatest ally when taking advantage of the compounding investment dollars. Planning and saving for retirement may seem like a goal that is far off in the future. However, retirement savings for women needs to start early and continue through their lifetime. Understanding that career interruption, part-time work, and wage differentials can severely hamper savings in a woman's financial plan is critical to her long term retirement success. As reported by the Department of Labor (2009), a female retiring at age 65 can expect to live another 19 years. Savings are necessary to ensure that she has enough money to see her through the retirement years. Barbara Lee (1996) states that, only $12 \%$ of women actively participate in the financial decision making in their own families. This is a shocking statistic since Lee also points out that at some point in their lifetime $90 \%$ of women will assume full time responsibility for the families' finances. Money is an integral part of everyday life and the management of this commodity should not be taken lightly.

\section{WHY DO WOMEN FALL SHORT?}

One of the most main obstacles women face in retirement planning is the wage differential. The Bureau of Labor acknowledges and documents the existence of the gender gap pay disparity (Boras). The factors that contribute to this problem are often debated. Occupational crowding is believed to create a large amount of the wage gap problems. This can be explained when predominantly female occupations experience downward wage pressure due to the large amount of women in these fields. A Washington Post (2007) concluded that women who work full time earn about $77 \%$ of the salaries of full time working men. However, this figure does not factor in educational level or differentiate between professions. When these factors are put in the equation, women still earn $11 \%$ less than men of equal experience and education. The wage gap is slowly becoming less prominent in recent years, but the damage has already been done for women who have been in the workforce for some time. These women cannot make up for years of lost wages. Their retirement benefits and personal savings are also affected by 
the wage gap. Many years of the compounding effect is lost due to the lower salaries with smaller residual amounts to invest.

Traditionally, women tend to pursue careers that have a lower earning potential. Salary is not the deciding factor when considering an occupation. Labor Review (2003) concludes that years of schooling and experience are the tools women need to positively impact the wage issues. Since more young women are attending college, the wage disparity should continue to decrease. By making personal choices to explore particular industries that are known to offer better pay, women can begin to narrow the gender wage gap. This will help young women entering the workforce, but not the females who have been working for many years. The Department of Labor (2007) postulates that, "management occupations dominated by women tend to be service related; while those dominated by men tend to be goods producing". Women tend to reach management levels in human resources, medical and health services, social and community services, and educational fields. These do not represent the highest median wage potential in management positions. The higher paying management jobs which consist of engineering and computer information systems tend to be predominantly male dominated. Therefore, lower salary professions and the wage inequalities continue to be a detriment to ill prepared retirement for women. This supports the theory that retirement planning for women poses different challenges than their male counterparts and a financial plan must be embarked upon as quickly as possible.

\section{RETIREMENT SAVINGS PLANS}

Another obstacle for women is that they tend to change jobs more frequently than men. It is reported that women over twenty-five years of age stay with the same employer for approximately 4.8 years as opposed to men who average 6.6 years (Patterson). These changes can cause costly interruptions in retirement savings. Many employers offer a $401 \mathrm{~K}$ plan or some other type of retirement account. It is best to join the plan as soon as possible and try to maximize contributions. Many employers match a certain percentage of the employee's contribution. According to the Department of Labor (2009), the most common match is 50 percent of the employee's contribution up to a maximum percentage of wages or salary. An employee must stay a certain number of years to become vested in the retirement plan. It is important to know what the vesting requirement is because it should be factored into a decision before changing jobs. Retirement benefits can be lost if the job change occurs before the vesting period is over. However, if vesting is achieved, the money should be reinvested in an IRA to continue growing. The money must be transferred directly to the IRA and the employee must not directly receive it or they could potentially be subject to tax consequences. Statistics from the Department of Labor (2009) reveal that, of the approximately 62 million eligible working women in the United States, only $45 \%$ are participating in a company sponsored retirement plan. Saving early can greatly enhance a woman's chance of having enough money to outlast her retirement years. Saving early and often benefits from the precious gift of time. The savings will grow and the earnings can enjoy the compounding effect. Setting an attainable savings target can help to provide security to a woman when she decides to quit working and savor retirement.

\section{CAREER GAPS}

Another deterrent to women's financial well being is that they are in and out of the work force more often than men. As a result, women are less likely to qualify for a pension. When a pension is earned, the amount of the pension is estimated to be approximately $50 \%$ of what their male counterparts receive (Taker). As stated in a report by the Institute for Women's Research, between 1970 and 1995 the number of women working in the labor force rose to 59\% from 38\% (Shaw). Women tend to have shorter and less lucrative careers, but remain in the labor force on a part time basis. Most employers do not offer benefits to part time employees. Smaller companies seem to be more attractive to female employees. They are afforded a more flexible work schedule to allow them time for family issues. The trade off for this quality of life option is often a smaller or nonexistent benefit package. Women are considered the nurturers of the family and often interrupt their careers for pregnancy, child care, elder care, or relocating because of a spouse's career plans. Unfortunately, these constant changes mean fewer dollars to contribute to a retirement savings plan. Since career gaps are much more prevalent in a woman's life, they must remember to make regular contributions to a retirement fund whenever the opportunity exists. 


\section{FINANCIAL STRESS IS GREATER FOR WOMEN}

As the United States economy has increased financial worries, women are even more worried than men about paying bills, losing jobs, providing for their children, and saving for retirement. Results of an American Psychological Association survey confirm that women report feeling more stress in a financial downturn (2008). Three categories where women reported additional stress include: the economy $84 \%$ for women versus $75 \%$ for men, money $83 \%$ for women versus $78 \%$ for men, and job stability $57 \%$ for women versus $55 \%$ for men. Much of the stress women feel is due to the fact that they are single parent households. As reported by the census bureau (2001), on in four children 18 and younger live in a one parent household. Of these children, almost nine in ten live with only their mother. This problem combined with lower paying jobs causes women to experience higher rates of economic anxiety compared to men. Many women feel they are not saving enough for retirement which increases their feeling of insecurity. The fact that women earn less during their working years, because of their care giving roles, the amount contributed to retirement savings plans and social security is less and therefore diminishes their retirement income.

\section{HIGHER LIVING EXPENSES}

Other pressures that can interfere with a woman's ability to fund her retirement account include, divorce, personal living expenses, and higher medical expenses. Taker (2007) states that many women choose to marry later in life or not at all. With the United States divorce rates of approximately 50\% and the fact that life expectancy is higher for women, there is a good chance that more women will approach retirement as a single female. This puts the entire responsibility of their financial health on their shoulders. In the event of a divorce a women will most often experience a decline in her standard of living. Women's Legal Defense Fund noted this decline to be in the order of approximately $25 \%$. The primary caregiver status normally falls to the mother and this can lead to living expenses rising substantially. General personal living expenses are also typically higher for women. Maintenance costs such as dry cleaning, haircuts, and clothing usually come with a higher price tag. Medical costs are usually higher for women, even when considering preventive care. The Centers for Disease Control (2000) and Prevention Magazine (2008), determined that medical costs for women are two to three times higher than for men. Since women are expected to live longer, medical costs can be a significant expense over a lifetime. These unforeseen expenses can impede a woman's savings target for retirement.

\section{WHAT RECOURSE DO WOMEN HAVE? START SAVING EARLY}

Saving early in a career affords a portfolio the opportunity to grow and take advantage of the compounding effect. Compounding allows money to multiply faster and faster or as Taker expresses this concept as "profiting on your profits". Social security benefits are generally not adequate to live on in retirement. As reported by the Social Security Administration (2007), the average benefit for women over 65 was $\$ 10,685$ per year as compared to $\$ 14,055$ for men. Since women have lower salaries, they do not contribute as much to social security resulting in a lower benefit. This represents a small amount of the funds necessary for retirement and should only be viewed as a supplement to a retirement fund. If a retirement plan is not available at a woman's place of employment, there are other options for her to begin a savings plan on her own. Anyone who receives wages or is married to someone receiving wages can contribute to an IRA. If a woman is self-employed, she may contribute to a Simplified Employment Plan (SEP-IRA) or a Defined Contribution Plan to help increase retirement savings. Time is an important element in meeting a savings target and the earlier one begins, the more one accumulates.

\section{FINANCIAL RESOURCES}

Careful review of the obstacles that may hinder a woman's journey to a fully funded retirement account needs to be the first step towards implementing an action plan. Navigating the road to wealth can become a stimulating and rewarding experience if a course is plotted to facilitate reaching the long range destination. Understanding and utilizing the many different financial resources available can help ensure smooth sailing to the ultimate goal. Women tend to relate to money differently than men. Security is their top priority and comparing risk versus reward is an integral part of their decision making. Personal attitudes towards money help women set a financial plan and determine their retirement objectives. Zweig (2209) states that, "women feel it is much more 
important than men to avoid incurring large losses, falling below a target rate of return and acting on incomplete information. In short, women are more risk-averse than men". They tend to shy away from investment opportunities which give them incomplete information. Emotions play a larger role in their decision making, which is not always a negative. Once a woman initiates a financial plan, her first imperative is safety. Looking long term and accepting lower risk investments with steady investment gains can prove beneficial over time. Patience is a virtue women seem to follow in the investment game. Women trade less frequently, hold less volatile portfolios and expect lower returns than men do. Given inefficiencies and market fluctuations in general, a slow and steady course can prove quite profitable.

\section{WOMEN - THE NEW INVESTORS}

Are women actually more savvy investors? Studies have shown that many women enjoy slightly higher rates of return than their male counterparts. Even with these results, women still feel less confident when it comes to investment decision making. Financial professionals still seem to have a bias in the way they treat female investors. C Money magazine indicates that brokers take female investors less seriously, do not value their business, spend less time on the client interview process, and are more likely to introduce riskier investments to male clients (Prince). Since women control 55\% of America's wealth, this seems short-sighted on the part of investment advisors. Women's investment groups have enjoyed higher rates of returns than their comparable all-male groups. Women believe in setting up a long term plan and adhering to the risk/reward criteria they are comfortable with. Over confidence is not considered a normal female trait, and the need to "beat the market" is not part of the overall game plan. "Trigger happy" men are also much more likely to boast about their portfolios performance. During bear markets, women tend to hold on to their investments. At this point, they are more apt to ask for professional help and turn to research to regain their sense of investment security. Their long term focus enables them to adopt a more buy and hold strategy and realize certain events are out of their control. . Barber and Odeon (2009) concluded that "women's risk adjusted returns beat those of men by an average of about one percentage point annually". Traditionally, women invest more conservatively than men. Choosing carefully where money is invested can increase growth opportunities. Women seem to manage their retirement investments equally as well as and sometimes better than their male counterparts due to the fact that they set realistic expectations, keep focused on a set strategy and tend to be long term investors.

\section{RETIREMENT STATISTICS}

“Only 5\% of Americans can afford to retire at age 65!" (Bach)

"The average retirement income for a woman over 65 is less than $\$ 7000$ a year" (Bach).

"Two-thirds of women over 65 rely on Social Security as their primary source of income. Consequently, women are twice as likely as men to live out their golden years at or below poverty levels... (Taker).

"Women need to keep in mind that their retirement career can be longer than your working career" (Prince).

"If a woman has $50 \%$ less service than a man, coupled with the fact they earn nearly $2 / 3$ rds of men's earnings means that a woman's retirement benefits will be one-fourth the size of her male colleagues" (Patterson).

\section{CONCLUSION}

The statistics above conclude what an overwhelming task retirement savings can present for women. Women must confront these detriments head-on and realize now is the time to act. Although wage inequalities are decreasing, this will not help the already large percentage of women in the workforce today. This group must increase its knowledge of retirement planning and recognize the benefits associated with taking control of its financial future. The first step is to make sure they are funding a retirement plan will help steer them toward long term financial well being. Retirement planning needs to be a priority in every woman's life and not viewed as something to worry about in the future. The time to plan for the future is now and a steady investment stream along with proper diversification can make the process manageable rather than trying to play catch-up down the road. 
Assuming a proactive role in the family finances now can increase confidence and knowledge so that if faced with the primary role at some point, the challenge will not seem so overwhelming. Sharing in the duty of monitoring the family finances can be rewarding for both spouses. A wife's ideas could help with diversification and safety and prove to be a complement to the overall portfolio. As women gain investment experience their financial portfolios grow. Knowledge breeds a certain degree of power. If security is indeed a woman's ultimate goal, financial education and confidence will help her to achieve financial independence. The silver lining for women is that no matter what age, it is never too late or early to begin the journey of financial and retirement planning.

\section{AUTHOR INFORMATION}

Dr. Naveen K. Malhotra is the professor of International Business and Finance at Eckerd College. He holds degrees from University of Delhi, University of Tampa, and the University of South Florida. He has widely published in the area of Lifelong Learning and International Business issues. As the Sam M. Walton Free Enterprise Fellow at Eckerd College, he directs the highly successful Students in Free Enterprise service-learning chapter. His team has repeatedly won its regional and national championships awards and has been widely recognized for its efforts by the City Council and the Mayor of St. Petersburg, Florida.

Maureen Witt is currently a Compliance Advisor for the Municipal Fixed Income department at Raymond James \& Associates in St. Petersburg, Florida. Her previous experience includes 25 years of underwriting and trading municipal bonds, which has transitioned well into helping her navigate today's challenging regulatory environment. Before joining Raymond James, she was a managing director with Royal Bank of Canada and an integral part of their national municipal bond underwriting team. She chose to continue her education at Eckerd College. Using her career experience, she became both a mentor and member of the school's Students in Free Enterprise team.

\section{REFERENCES}

1. American Psychological Association. (2008 October). Americans Stressed Over Economy - More Report Symptoms.http://www.apapractice.org/apo/in the news/americans stressed.html\#

2. $\quad$ Bach, David (2002). Smart Women Finish Rich. New York: Broadway Books. pp. 3-30.

3. Boraas, Stephanie \& Rodgers, William M. Bureau of Labor Statistics. (2003 Mar)The Earnings Gap. http://www.bls.gov/opub/mlr/2003/03/art2full.pdf

4. Center for Disease Control and Prevention. (2008 August). Costs of Falls Among Older Adults. http://www.cdc.gov/ncipc/factsheets/fallcost.htm

5. Jupiter, Marlene (1998). Savvy Investing for Women, Strategies from a Self-Made Wall Street Millionaire, New Jersey: Prentice Hall Press. pp. 4, 261-295.

6. Lee, Barbara (1996). Financially Independent Woman, a Step-By-Step Guide to Successful Investing, New Jersey: Carol Publishing Group. pp. 162-163.

7. Patterson, Martha Priddy (1993). The Working Woman's Guide to Retirement Planning, Saving and Investing Now for a Secure Future, New Jersey: Prentice Hall. pp. 4-26.

8. $\quad$ Prince, Francie \& Pi, Douglas. (1996). Every Woman's Guide to Investing, 11 Steps to Financial Independence and Security, California: Prima Publishing. pp. 5-19.

9. Shaw PhD, Lois \& Hill PhD, Catherine. Institute for Women's Policy Research. (2002). The Gender Gap in Pension Coverage. http://www.iwpr.org/pdf/d447.pdf

10. Social Security Administration, (2008, October). Social Security is Important for Women. http://www.socialsecurity.gov/pressoffice/factsheets/women.htm

11. Ted: The Editor' Desk. (2008, October). Women's Earnings as a Percentage of Men's, 1997-2007. http://www.bls.gov/opub/ted/2008/oct/wk4/art03

12. Thakor, Manisha \& Kedar, Sharon. (2007). On My Own Two Feet, Massachusetts: Adams Media. pp. 12, 63-66.

13. U. S. Census Bureau. (2001 May) Family Composition. http://www.census.gov/Press-Release/cb9888.html

14. U. S. Department of Labor. (2007 October). Highlight of Women's Earnings in 2007. http://www.bls.gov/cps/cpswom2007.pdf 
15. U. S. Department of Labor. (2009). Women and Retirement Savings.

http://www.dol.gov/ebsa/publications/women.html

16. U. S. Department of Labor. (2007 May). Wages for Predominantly Male and Predominantly Female Management Occupations. http://www.bls.gov/oes/2007/may/figure13.pdf

17. Vedantam, Shankar (2007 July 30). Salary, Gender and the Social Cost of Haggling. The Washington Post, p. A7.

18. Zweig, Jason (2009 May 9). For Mother's Day, Give Her Reins to the Portfolio. The Wall Street Journal. p. B1. 